\title{
Analysis Towards The Current Management Of Limited Common Property In Malaysia
}

\author{
Tan Wee Vern, Tan Liat Choon, Toh Ming Liang, Nabilah Huda Binti Yaccub, Muhamad Uznir \\ Bin Ujang, Thoo Ai Chin
}

\begin{abstract}
Strata properties in Malaysia were getting popular especially in the urban areas. As the population density in urban centres are expected to grow continuously, the number of residents for strata properties are expected to rise continuously which help to promote the mix-developments to be developed under a strata scheme. However, there are some issues regarding the unfair management for the common property in mixdevelopment where certain owners have to pay the maintenance fee for common properties which are not enjoyable by them. Therefore, this paper has the objective to examine the current practice of strata management towards limited common property. The enactment of Strata Management Act 2013 and enforcement in 2015 promoted the self-governance for strata scheme in Malaysia. For the current strata property, the scheme will be managed by all strata unit owners where Strata Title Act 1985 and Strata Management Act 2013 provide the framework in establishing the Management Corporation to administer and manage the strata scheme. MC is allowed to establish Subsidiary Management Corporation (Sub-MC) to manage limited common property and the designation of limited common property for different interest of parcel proprietors especially for mixdevelopment properties. Although the frameworks and procedures to establish the subsidiary management corporation were introduced under the Circular of JUPEM in 2017, however the number of establishment for Sub-MC is still low as there is only Sub-MC in Malaysia was proposed to be formed at 1 Mont' Kiara mixed-use stratified development. Quantitative method and descriptive analysis were used in this research. Result shows that the management body has the knowledge in forming limited common property in their strata scheme. However, the low number in forming limited common property might due to problems in the procedure. Therefore, common pool resource theory was applied to describe the benefit in forming the limited common property.
\end{abstract}

Keywords: Strata Scheme, Subsidiary Management Corporation, Limited Common Property.

\section{INTRODUCTION}

Nowadays, strata properties are getting popular for property development in Malaysia. This was proven by more than 20 per cent of Malaysians which equivalent to over 6 million people are living in strata properties [1]. Strata properties under Strata Titles Act 1985 include the

Revised Manuscript Received on April 19, 2019.

Tan Wee Vern, Faculty of Built Environment and Surveying, University Teknologi Malaysia, Skudai, Johor, Malaysia.

Tan Liat Choon, Faculty of Built Environment and Surveying, University Teknologi Malaysia, Skudai, Johor, Malaysia.

Toh Ming Liang, Faculty of Built Environment and Surveying, Universiti Teknologi Malaysia, 81310 Skudai, Johor, Malaysia

Nabilah Huda Binti Yaccub, Faculty of Built Environment and Surveying, University Teknologi Malaysia, Skudai, Johor, Malaysia.

Muhamad Uznir bin Ujang, Faculty of Built Environment and Surveying, Universiti Teknologi Malaysia, 81310 Skudai, Johor, Malaysia.

Thoo Ai Chin, Azman Hashim International Business School, Universiti Teknologi Malaysia, 81310 Skudai, Johor, Malaysia. building parcels and land parcels where building parcels mean any buildings on alienated land under a final title which have two or more storeys and capable of being subdivided into parcels. Meanwhile, land parcels mean any alienated land to be held as one lot under a strata title or as an accessory parcel which have two or more buildings held as one lot under a final title where the building could not exceed four storeys and capable of being subdivided into land parcels [2].

Under the legislation for strata properties in Malaysia, strata titles were first introduced as subsidiary titles under the National Land Code 1965 in Peninsular Malaysia. Due to rapid development in Malaysia, the Strata Titles Act 1985 (Act 318) come into existence to improve the inadequate provisions under National Land Code 1965. Following of that, Strata Titles Act 1985 was amended several time to ensure improvement of legislation and meet the requirements for strata properties.

The amendment was first in 1990 under Act A753 which introduced the provisional strata titles in Strata Titles Act 1985 followed by 1996 where land under the Qualified Title may apply for strata titles with the approval of Certified Plan under Act A951. In 2001, the Strata Titles Act was amended under Act A1107 with the introduction of Strata Titles Board. Under Act A1107, there was the beginning of entry for the registrar caveat and fines to the owners who fail to apply subdivision. Strata properties include land parcels in the year of 2007 where Strata Titles Act was amended under Act A1290 indicate that strata properties not only for high-rise building but also extended to any alienated land which have two or more buildings and could not exceed four storeys building. The amendment of Act A1290 was along with the consequence of the Building and Common Property (Maintenance and Management) Act 2007 (Act 663). Under Act 663, there was beginning of selfgovernance for the strata corporation system which known as 'Management Corporation' which will be formed among the proprietors.

However, in 2013, Act 663 was appealed and replaced by the enactment of Strata Management Act 2013. Strata Titles Act (Act 318) was amended once again to meet the requirement under the enactment of Strata Management Act 2013 under Act A1450. Act A1450 which known as Strata Titles (Amendment) Act 2013 (STAA 2013) introduced limited common property and subsidiary management corporation to overcome the unfair management where certain parcel owners have to pay the 
management fee for the common property that is not enjoyable by them. For the latest amendment of Strata Titles Act 1985 under Strata Titles (Amendment) Act 2016 (Act A1518) introduced the rent of parcel to ensure rent will be responsible by respective proprietors and solve the problem of arrears for rent which will affect the whole management corporation operation.

The Strata Management Act 2013 (Act 757) was published in the Gazette on 8 February 2013 in conjunction with Act A1450 [3]. Both Acts have come into force on 1 June 2015 in the Peninsular Malaysia except the State of Penang and Federal Territory of Labuan. Meanwhile, the State of Penang was come into force on 12 June 2015. In the year 2013, the strata properties come into new era whereby major changes towards the features of legislation include the delivery of vacant possession along with strata titles have been issued. Moreover, Strata Management Tribunal was established to replace Strata Titles Board to resolve any disputes or arguments arise under strata properties.

For the current strata properties management, all the strata scheme will be governed by all strata unit owners where Strata Titles Act 1985 (Act 318) provides the framework for establishing the management corporation (MC) to administer and manage the strata scheme [4]. Those management corporation will be formed after 25 per cent of aggregate share units transferred either after Joint Management Body period if without strata titles or after developer period if strata title was issued. The establishment of management corporation (MC) is compulsory for all strata scheme and is the duty of the developers. The management corporation was governed by members of management committee which are consist of strata unit owners or proprietors.

Under the institutional for strata properties in Malaysia, management corporations play important roles which is one of the two main bodies given the powers and duties in the aspect of governance of strata schemes in Peninsular Malaysia and Federal Territory of Labuan along with Commissioner of Building (COB) under the Strata Titles Act 1985 and Strata Management Act 2013. Whenever related to settle dispute in strata properties, there is another body which is Strata Management Tribunal (SMT) has the power in jurisdiction after the action in any court of competent jurisdiction [5].

The main function for the establishment of management corporations is to manage and administer the strata scheme where all the parcels or all parts of building which are not owned by the individuals are categorized as common property. Management Corporation has the duties in relation to account, records, maintenance and management for the parcel owners and common property. The Management Corporation will act as proprietor for the common property where common property is owned by strata unit owners as tenants in common [3]. The owner cannot separate his or her interest in strata lot from the interest in the common property or common assets where owner could not sell the proportionate of common property separately from their strata lot.

In Malaysia, Strata Titles Act 1985 interprets common property which is an area that not included in any parcel, accessory parcel or provisional block. The common property facilities in the strata scheme is under the duties of Management Corporation to maintain and repair the common property in a good and serviceable repair condition. The example of common properties are corridor, lift, playground and swimming pool in a strata scheme.

In the year of 2013, the major change in strata legislation is the introduction of establishment for the limited common property and subsidiary management corporation. After the enactment of Strata Management Act 2013 (Act 757), Management Corporation was allowed to establish Subsidiary Management Corporation to manage limited common property. Under Section 17A of Strata Titles Act 1985, Management Corporation may designate limited common property for different interest of parcel proprietors in a strata scheme which benefited for limited proprietors who can enjoy the limited common property but not all proprietors. The identification of limited common property is useful and significant in determine the proprietorship for certain owner who has exclusive benefit towards the limited common property (LCP) and forming the subsidiary management corporation (Sub-MC). Meanwhile, strata unit owners who is not enjoy the benefit of limited common property do not need to pay for the charges related to the limited common property which are fair to them.

\section{PROBLEM STATEMENT}

Since strata scheme emphasized the responsibilities on the common properties was shared among the proprietors, the Management Corporation (MC) plays the duties and powers to ensure the status of common property is in good condition. Related to the limited common property (LCP), $\mathrm{MC}$ has the power to create one or more than one subsidiary management corporation (Sub-MC) to manage the related LCP. MC shall delegate all the duties and powers in relation to limited common property to subsidiary management corporation and ensure Sub-MC was performed well in management and maintenance duties for the LCP. However, the formation of the Sub-MC will depend on existing common property only enjoyed by some unit of strata unit owners [1] and there is a need to form subsidiary management corporation when the comprehensive resolution was passed among the votes of proprietors which require two-third (2/3) of the aggregate share units based on all the parcels owned by proprietors.

Nevertheless, there is difficult to form Sub-MC due to the requirement to have consent of at least two per three (2/3) of aggregate share units of all strata unit owners to form SubMC under the Strata Management Act 2013. The requirement to have comprehensive resolution to be passed is compulsory to form Sub-MC for the strata scheme. Besides that, the formation of limited common property required the special plan to be prepared by a land surveyor under Strata Titles Act 1985 (Act A1450) which took long period for the Management Corporation. Even though there is Circular from JUPEM describes the procedure for establishment of limited common property with the time 
frame [6], but there is no time frame for license land surveyor to produce the special plan. This difficulty hinders the formation of Sub-MC in the practice of strata property in Malaysia.

Even though the Strata Management Act 2013 and Strata Titles Act 1985 have been introduced clearly about the establishment of Sub-MC and LCP, however the establishment of Sub-MC could be an optional in a strata property [1]. The establishment will be depended on all the strata unit owners requirement whether is suitable and require to have Sub-MC in the strata scheme. This is because Management Corporation could carry out the duties as subsidiary management corporation if the strata unit owners think there is no requirement to designate limited common property or establishment of Sub-MC.

Currently in Malaysia, different types of property within a strata scheme have to be correctly identify the common property and limited common property. Even though the Sub-MC and LCP have been introduced since the year of 2013 in Strata Titles Act 1985 and Strata Management Act 2013, there was only first Sub-MC was proposed to be formed [7]. Edge Prop reported the first Sub-MC is set to be formed at 1 Mont' Kiara mixed-use stratified development. There will be total of three Sub-MC proposed to be formed which is the first sub-MC will be managing i-Zen Kiara II, the second for Menara $1 \mathrm{MK}$ following by the third will be for Wisma Mont' Kiara and 1 Mont' Kiara. This report shows that the formation of LCP and Sub-MC are less implement in Malaysia although it was so important especially for mixed-development strata property.

In addition, currently Management Corporation (MC) unable to control the Sub-MC if the Sub-MC are unable to perform up to par unless through by-laws set by the MC. Subsequently the management corporation (MC) shall think the solution if the Sub-MC are not performed well either to regain the control to the limited common property (LCP) or any better solution. For the current strata practice in Malaysia, it was two-tier system [8] which is management corporation (MC) manage together with the Sub-MC. Whenever there was dispute arise between MC and Sub$\mathrm{MC}$, they have to decide whether to refer to the Commissioner of Building (COB) or Strata Management Tribunal (SMT).

This research has the objectives to:

a) examine the current practice of strata management towards limited common property.

b) describe the advantages in forming subsidiary management corporation and establish limited common property in strata scheme.

\section{STRATA PROPERTY}

Strata property under the strata titles act 1985 includes parcels, land parcels, common properties and provisional blocks. Therefore, every rights under the strata scheme shall be clearly define under the strata titles to avoid any disputes that will arise in the strata scheme. Other than that, strata management act also plays important roles in the strata scheme. Even though strata management act not a custody for the rights of proprietor, the rules and regulations inside this act will be guidelines to be followed by all the strata scheme corporation, proprietors and occupiers.

\section{A. Strata Property Right}

Whenever related to property rights of Malaysian property owners, it has to be determined through legislation [9]. It is possible for property rights for different types of facilities, either below ground, above ground surface or both [10]. This is because several parties can simultaneously use one parcel. Strata Titles Acts 1985 enactment is to ensure all the rights for proprietors are protected under their respective strata titles.

All the proprietors have their rights as a proprietor to their respective parcel and common property. In relation to their parcel, proprietors have to follow their proprietor rights according to National Land Code 1965 for the dealings of their parcels. Meanwhile, in relation to the common property, the proprietor has the right of user which they have exclusive benefit and their proprietorship towards the common property is based on the share unit in the strata scheme. Under Section 34 of Strata Titles Act 1985, the proprietor shall not dispose independently in relation to their accessory parcels.

\section{B. Management Corporation}

Management Corporation (MC) will be established automatically and will be issued certificate of Management Corporation once the opening of book of strata register [8]. Under the Strata Titles Act 1985, any subdivided building or land shown in a certified strata plan will be governed by the management corporation. In other words, this means that Management Corporation will be the proprietor for common property of strata scheme and the custodian of the issue document of title of the lot under Section 17B of Strata Titles Act 1985.

Management Corporation shall be formed once 25 percent or more allocated share unit have been transferred to the respective proprietors within one month under the Strata Management Act [1]. Under the Strata Management Act 2013, there will be developer's duty to organise first annual general meeting for the MC to elect the management committee [11]. The management corporation will be managed by management committee consist of three to fourteen members which is depend on the management corporation requirement. There shall without the involvement of developers for the management committee. The main duties and powers of management corporation are to maintain and manage the common property and subdivided building or land in good and serviceable repair. Management Corporation shall also control and manage the maintenance account and sinking fund account.

\section{Common Property}

Generally, common property defines as the joint, nonexclusive entitlement condition where the resource owners have a joint claim on the resource prior to capture or use [12]. Related to common property, all the individuals or proprietors shall have rights and obligations in common with all other users or proprietors [9]. Meanwhile common property under strata scheme define in Strata Titles (Amendment) Act 2013 (Act

1450) means that the lot that

Published By:

Blue Eyes Intelligence Engineering

$\&$ Sciences Publication

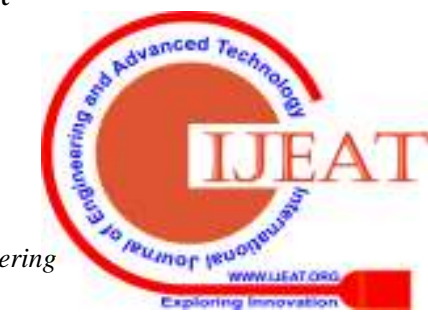


not included as any individual parcel including accessory parcels or any provisional blocks determined by the certified strata plan. Other than that, Strata Management Act 2013 means common property as the building or land intended for subdivision into parcel or subdivided to be used or enjoyed by at least two or more parcels occupiers or strata unit owners. Common property include all parts of the building and land that do not forms parts of an individual parcel in the strata scheme, which is managed by the Management Corporation or body corporation of the strata scheme on behalf of all the proprietors [13].

In relation to common property, since Management Corporation will act as proprietor for the common property, therefore management corporation shall has the duties to maintain and manage the common property and ensure it in a good and serviceable repair condition. Management Corporation shall has the power in authorized expenditure for carry out maintenance and management for the common property using the maintenance account and sinking fund account.

\section{Subsidiary Management Corporation}

Subsidiary Management Corporation shall be formed upon the issuance of a certificate of its establishment by the Director of Land and Mines under Section 17A Strata Titles Act 1985 [1]. The establishment of subsidiary management corporation is optional and depends on the management corporation, establishment of subsidiary management corporation is subject to pass the comprehensive resolution under Strata Management Act 2013 which require the consent of at least two-third of the aggregate share units owned by the proprietors.

Management Corporation has the duty within one month after the issue of certificate of subsidiary management corporation to organise the first annual general meeting to elect the subsidiary management committee to carry out the duties of Sub-MC. The Sub-MC formed by all the strata unit owners who has the exclusive benefit on the limited common property but not all strata unit owners. There is requirement for the subsidiary management committee to reserve one seat for the member of the management committee of the MC. The main duty of subsidiary management corporation is to maintain and manage the limited common property in a good and serviceable repair condition.

\section{E. Limited Common Property}

Limited common property (LCP) is essential especially to any mixed and integrated development with multi usage within a strata scheme [11]. It is allowing a fair distribution in relation to the payment of service charges whereby the certain strata unit owners who did not share certain common property. For example, the residential owners who did not enjoy the exclusive benefit of common property for retail usage. A LCP is initially one of the common property of a strata development that is delineated as belonging to a subsidiary management corporation for the exclusive benefit for certain proprietors whereby is in the same way that common property is run and managed by the main MC [14]. corporation. If there is a requirement by the management

Under the Strata Titles Act 1985, LCP shall describe, identify or define the boundaries or area in a special plan. Licensed Land Surveyor has the responsibility to prepare the special plan for limited common property which describe, identify or define the boundaries or area. Under the Strata Management Act 2013, LCP means that part of the common property in a lot that has been designated for the exclusive benefit of the strata unit owners of two or more but not all of the strata unit owners. Limited common property was established once the certificate of subsidiary management corporation has been issued certifying subsidiary management corporation being constituted.

\section{F. Common Pool Resource Theory}

Common Pool Resource (CPR) Theory to be applied in describe the benefit in managing the limited common property. Common Pool Resource Theory [15] designed for the eight main principles enduring common institution which are:

1. Clearly defined boundaries

Membership have the rights to withdraw resource from common resource while the physical boundaries are clearly defined.

2. Congruence between appropriation and provision rules and local conditions

The distribution of benefits roughly proportionate to the costs imposed by provision rules.

3. Collective choice arrangements

The affected parties can participate in modifying operational rules.

4. Monitoring

Audit the common pool resource conditions and appropriator behaviour which accountable to the appropriators.

\section{Graduated Sanctions}

Appropriators who violate operational rules or against the regulation are likely to receive graduated sanction or punishment depending on the seriousness and context of the offense.

6. Conflict-Resolution Mechanisms

The appropriators shall ready to access conflict resolution mechanisms in resolve the conflict among appropriators and shall have rapid access to low-cost and within local arenas.

7. Minimal Recognition of Rights to Organize

The rights of appropriators to devise their own institutions are not challenged by external governmental authorities.

8. Nested Enterprises

Define as larger systems include appropriation, provision, monitoring, enforcement, conflict resolution and governance activities are organized in multiple layers in nested enterprises.

\section{METHODOLOGY}

This research is conducted using the Quantitative Method through questionnaire survey to analyse the understanding of the management body towards limited 
common property and subsidiary management corporation. 30 questionnaire surveys were distributed to the management body which are joint management body and Management Corporation in the Johor Bahru District to get the respond from these respondents about their ability in differentiate common property and limited common property.

The details of procedures in establish subsidiary management corporation and limited common property will be obtained from secondary data such as circular, acts and books.

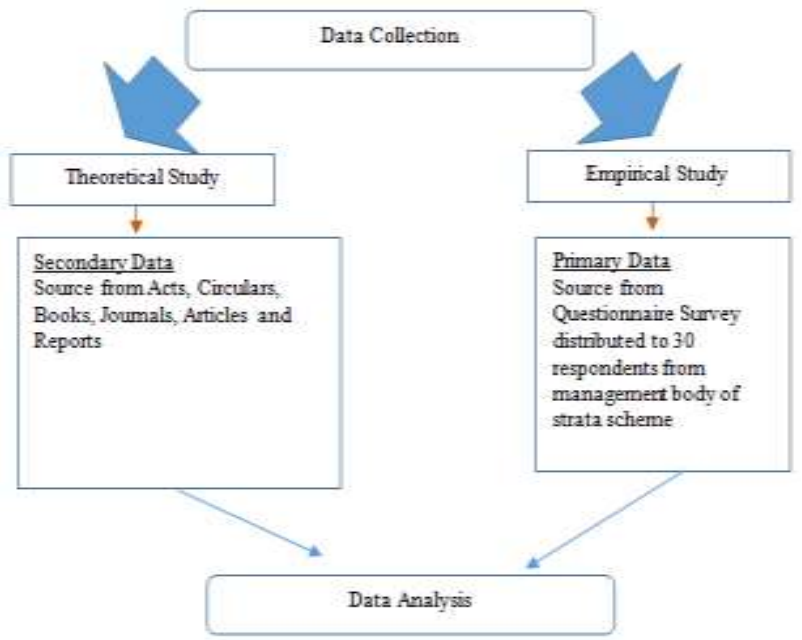

Figure 1: Methodology Flowchart

\section{RESULTS AND FINDINGS}

Results showed the procedure of establish the subsidiary management corporation. The empirical study results were obtained through the analysis from the questionnaire survey. 30 respondents' results were analysed to know the management body in the strata scheme towards their knowledge about the Sub-MC in managing the LCP. Other than that, the results also interpret whether management body know the differentiation between common property and limited common property.

A. The Procedure In Establish The Subsidiary Management Corporation And Limited Common Property

The procedure in forming Sub-MC and LCP are as shown as below:

Licensed Land Surveyor (LLS) or Management Corporation (MC) submit application with Limited Common Property (LCP) file number and Limited Common Property plan along with the relevant document to Department of Survey and Mapping Malaysia (JUPEM).

Director of Survey from JUPEM shall provide the LCP file number, land survey field book number and special plan number

Once received the document from JUPEM, LLS or MC shall send the application the State Land and Mines Office using form 9 in Strata Titles Act 1985 after passed the comprehensive resolution.

State Land and Mines Office shall send the special plan received from LLS or MC to JUPEM or Director of Survey for approval.

Upon JUPEM received the special plan, shall open file related to the special plan of LCP for approval. JUPEM shall start to check special plan within 7 days submitted by LLS or MC and the application has to be completed within 30 days after received. Any correction needed shall be send to LLS for correction to get the approval of JUPEM.

After the approval by Director of Survey for the special plan, they shall notify to the State Land and Mines Office. State Land and Mines Office if satisfy with the application upon approval shall issue the certificate of establishment for the subsidiary management corporation (Sub-MC).

Figure 2: Process of the application to get certificate of Sub-MC 
However, before application to get the certificate of Sub$\mathrm{MC}$, the MC shall hold the annual general meeting (AGM) of $\mathrm{MC}$ to get the comprehensive resolution from the strata unit owners. After get the certificate of Sub-MC, there will be requirement for $\mathrm{MC}$ to organise the first AGM to elect the subsidiary management committee within one month after issuance of certificate of Sub-MC. The process of holding the first annual general meeting as follow:

\section{Before the AGM}

MC to serve notice (Form 16 SMA 2013) to every strata owner who constitute Sub-MC. The Notice shall include place, date, time, proposed resolution, voting rights and a copy of audited account for the meeting.

7 days before the AGM

Strata owners who constitute the Sub-MC to fully settle all or any part of the Charges, or contribution to the sinking fund and any payable money due to MC for his parcel.

48 hours before the AGM

$\mathrm{MC}$ shall put a list of names of persons entitled to vote in during the AGM. Those proprietors who constitute the Sub-MC shall submit appointment of proxy to the MC if applicable.

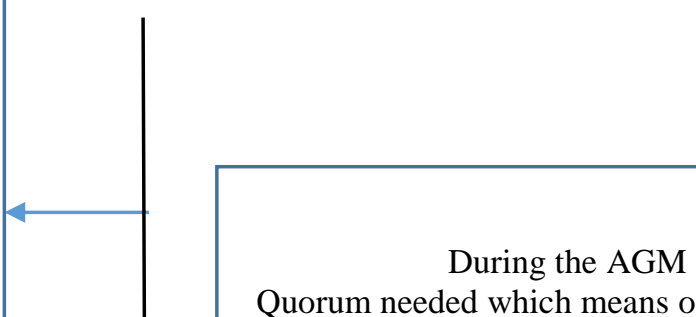

which means one half of the strata owners who entitle to vote present. If within half an hour after the time appointed for meeting, a quorum is not present, those proprietors present shall constitute a quorum.

\section{8 days after the AGM}

Sub Management Committee shall issue Notice of Resolution confirming Charges, Contribution to sinking fund in Form 17 to Strata owner who constitute Sub-MC. Sub management committee shall extend copy of minutes to all strata owners and display on notice board and file to Commissioner certified true copy audited accounts, report and minutes.

Within 15 months after the AGM Re-election Sub management committee shall hold the office for consecutive terms.

Figure 3: The process to hold first annual general meeting of Sub-MC

B. Analysis on The Knowledge Of Management Body Towards Limited Common Propert

Table 1: Respondent Details Types of Management Body

\begin{tabular}{lll}
\hline Details & Frequency & $\begin{array}{l}\text { Percent } \\
(\%)\end{array}$ \\
\hline $\begin{array}{l}\text { Management } \\
\text { Corporation }\end{array}$ & 15 & 50 \\
\hline
\end{tabular}

\begin{tabular}{|c|c|c|}
\hline $\begin{array}{l}\text { Joint } \\
\text { Body }\end{array}$ & Management 15 & 50 \\
\hline Total & 30 & 100 \\
\hline
\end{tabular}

To avoid bias result, this research was distributed the respondents equally among the management corporation and joint management body in order to observe their knowledge about subsidiary management corporation and limited common property. 15 respondents from representative of Management Corporation and 15 respondents from representative of joint management body. 
Table 2: Types of Strata Property

\section{Types of Strata Property}

\begin{tabular}{lll}
\hline Details & Frequency & $\begin{array}{l}\text { Percent } \\
(\%)\end{array}$ \\
\hline Apartment & 21 & 70 \\
\hline Condominium & 9 & 30 \\
\hline Total & 30 & 100 \\
\hline
\end{tabular}

This study is carry out 70 per cent at the apartment while 30 per cent at the condominium in the Johor Bahru District to get to know the knowledge of respondents on the limited common property.

Table 3: Knowledge in Differentiate the Management Corporation and Subsidiary Management Corporation

\begin{tabular}{lll}
\hline Details & Frequency & $\begin{array}{l}\text { Percent } \\
(\%)\end{array}$ \\
\hline Yes & 28 & 93.3 \\
\hline No & 2 & 6.7 \\
\hline Total & 30 & 100 \\
\hline
\end{tabular}

Result shows that only 2 equivalents to 6.7 per cent respondent do not know the function of subsidiary management corporation in the strata scheme whole 93.3 per cent know their functions. Most of the management body in Johor Bahru knows the existing of the subsidiary management corporation in the Strata Management Act 2013 and can be establish under the strata scheme.

Table 4: Knowledge in Differentiate the Common Property and Limited Common Property

\begin{tabular}{lll}
\hline Details & Frequency & $\begin{array}{l}\text { Percent } \\
(\%)\end{array}$ \\
\hline Yes & 24 & 80 \\
\hline No & 6 & 20 \\
\hline Total & 30 & 100 \\
\hline
\end{tabular}

This result indicates that around 20 percent of strata management body actually do not know the different between common property and limited common property. Even though 80 percent of management body in Johor Bahru knows the differentiate of this two types of common property, but 20 percent of management body who do not know about limited common property means the lower practice of establishment of limited common property to separate the boundaries of this two types of common property. Thus, mixed development property in Johor Bahru town less practice the establishment of limited common property although it was important for the strata scheme.

Table 5: Agree to Pay Charges for Their Respective Strata Scheme

\begin{tabular}{lll}
\hline Details & Frequency & $\begin{array}{l}\text { Percent } \\
(\boldsymbol{\%})\end{array}$ \\
\hline Yes & 18 & 60 \\
\hline No & 12 & 40 \\
\hline Total & 30 & 100 \\
\hline
\end{tabular}

The obtained result shows that 40 percent of respondents did not agree to pay charges for the common facilities they enjoy in the strata scheme. This indicate that they did not know the important of charges under their strata scheme. Nevertheless, the number will be higher for the common property that they did not enjoy the exclusive benefit and not the user for this common property. Since they did not agree to pay maintenance fee for their respective strata scheme, this could indicate that they actually did not know the benefit they obtain from the charges that they pay to the management corporation. Therefore, there shall be requirement to establish the limited common property in Johor Bahru area for the strata scheme from the result obtained.

Table 6: Perspective Toward The Establishment of Subsidiary Management Corporation

Establishment of Subsidiary Management
Corporation will be convenient for the strata scheme

\begin{tabular}{lll}
\hline Details & Frequency & Percent
\end{tabular}

\begin{tabular}{lll}
\hline Strongly Disagree & 1 & 3.33 \\
\hline Disagree & 3 & 10 \\
\hline Not Sure & 7 & 23.33 \\
\hline Agree & 12 & 40 \\
\hline Strongly Agree & 7 & 23.33 \\
\hline Total & 30 & 100 \\
\hline
\end{tabular}

From the result above shows that most of the 
management body knows that the benefit of establish subsidiary management corporation and limited common property for their respective strata scheme. However, about 23 percent of respondents actually did not sure whether the appearance of subsidiary management corporation bring benefit to the strata scheme. Therefore, the low number of subsidiary management corporation and limited common property establishment in Malaysia could be due to the management body who actually do not know the benefit in establishment the limited common property.

\section{Summary from The Results}

Overall from this finding proved that most of the management corporation understand and have the knowledge about the establishment of subsidiary management corporation (Sub-MC) in managing limited common property (LCP). However, they might not actually know the benefits and importance of the establishment of Sub-MC. The establishment of Sub-MC will provide benefit in fair distribution of charges where strata unit owners who did not enjoy the benefit of common properties do not need to pay for the charges, they only need to pay for their enjoyment of such LCP. Since this result indicate that most respondents did not agree to pay charges for their strata scheme, therefore the boundaries for LCP shall be established for their respective strata scheme if they did not enjoy the benefit.

This result indicates the reason why the number of SubMC and LCP established are low in Malaysia, as many management body actually did not sure the benefit of establishment of LCP. Another reason of low number of establishment of LCP might due to the problems occur during the procedures to obtain certificate of Sub-MC. Therefore, Common Pool Resource Theory will be applied to describe the benefit of establishment of subsidiary management corporation.

\section{Analyse Common Pool Resource Theory for Limited} Common Property

Another part of the finding will apply the Common Pool Resource Theory to analyse the management of the limited common property which could be the guideline to encourage the establishment of subsidiary management corporation in managing the limited common property in Malaysia. This analysis will describe the benefit of establish the limited common property using Common Pool Resource theory. The benefit will be based on the eight main principles show in Table 7.

Table 7: Common Pool Resource Theory in Describe the Limited Common Property

\begin{tabular}{|l|l|}
\hline Principles & Description \\
\hline $\begin{array}{l}\text { 1. Clearly defined } \\
\text { boundaries }\end{array}$ & $\begin{array}{l}\text { Boundaries on limited common property are clearly defined in the special plan } \\
\text { which is prepared by the Licensed Land Surveyor appointed by the Management } \\
\text { Corporation while the special plan has to be checked and get the approval from the } \\
\text { Director of Survey. Therefore, there will be benefit where no issue can arise } \\
\text { relating to boundaries of limited common property as special plan as the guideline } \\
\text { in describe, identify or define the boundaries and area of the limited common } \\
\text { property. }\end{array}$ \\
\hline $\begin{array}{l}\text { Congruence between } \\
\text { appropriation and provision } \\
\text { rules and local conditions }\end{array}$ & $\begin{array}{l}\text { Establishment of limited common property ensure the exclusive benefit and the } \\
\text { proprietorship for the strata unit owners who involve to constitute the subsidiary } \\
\text { management corporation. Meanwhile, another benefit is the fairness in distribute } \\
\text { the charges where proprietors under one strata scheme who did not enjoy the } \\
\text { benefit of limited common property do not need to pay for charges of the limited } \\
\text { common property. }\end{array}$ \\
\hline $\begin{array}{l}\text { Collective-choice } \\
\text { arrangements }\end{array}$ & $\begin{array}{l}\text { The strata unit owners who constitute the subsidiary management corporation has } \\
\text { the rights to decide as a proprietor in relation the limited common property. The } \\
\text { parties could file notice of motion in the first annual general meeting to be voted } \\
\text { during the first annual general meeting. Each proprietor who form the subsidiary } \\
\text { management corporation has the voting rights according to their share unit } \\
\text { entitlement in the limited common property. Each proprietor who form the } \\
\text { subsidiary management corporation shall entitle to be elect as subsidiary } \\
\text { management committee where they could make decisions in the corporation. }\end{array}$ \\
\hline
\end{tabular}




\begin{tabular}{|c|c|}
\hline Monitoring & $\begin{array}{l}\text { The subsidiary management corporation was monitored by the Management } \\
\text { Corporation and Commissioner of Building from time to time to ensure they } \\
\text { perform their duty as management body towards the limited common property. As } \\
\text { there was two-tier system for the limited common property, therefore there shall } \\
\text { reserve one seat of subsidiary management committee to the member of } \\
\text { Management Committee for the purpose to monitor their performance in managing } \\
\text { limited common property. }\end{array}$ \\
\hline Graduated Sanctions & $\begin{array}{l}\text { The limited common property is same as common property which is regulated by } \\
\text { By-Law in the Strata Management Act } 2013 \text {. Any proprietors or occupiers of } \\
\text { limited common property who against the regulation shall be punished fine as } \\
\text { stated in the By-law for the limited common property. }\end{array}$ \\
\hline $\begin{array}{l}6 . \quad \text { Conflict } \\
\text { mechanisms }\end{array}$ & $\begin{array}{l}\text { Strata Management Tribunal will be the party who responsible to solve any } \\
\text { disputes arise for related to the limited common property. Strata Management } \\
\text { Tribunal has the power in jurisdiction after the action in any court of competent } \\
\text { jurisdiction. }\end{array}$ \\
\hline $\begin{array}{l}7 . \text { Minimal recognition } \\
\text { of right to organize }\end{array}$ & $\begin{array}{l}\text { All the strata unit owners who constitute the subsidiary management corporation } \\
\text { shall have the right as proprietor to the limited common property stated in the Strata } \\
\text { Titles Act } 1985 \text {. The special plans indicate the right of proprietor to the limited } \\
\text { common property according to their respective share unit entitlement. Meanwhile, } \\
\text { the management of the limited common property will be self-governance by the } \\
\text { subsidiary management corporation without any authorities involve except } \\
\text { monitoring their performance. }\end{array}$ \\
\hline Nested enterprises & $\begin{array}{l}\text { The current regulation under Strata Titles Act } 1985 \text { and Strata Management Act } \\
2013 \text { are sufficient for the overall management towards the limited common } \\
\text { property. However, the legislation will be amended from time to time to ensure it } \\
\text { meet the requirement of the strata property and the rights. }\end{array}$ \\
\hline
\end{tabular}

\section{CONCLUSION}

Generally, the establishment of limited common property has a clear guideline provided by the Circular of the JUPEM in 2017. Strata Management Act 2013 has clear guideline as well for passing the comprehensive resolution and hold the first annual general meeting. Although there was guideline of establish the subsidiary management corporation in managing limited common property, the number of establishment of limited common property are low in Malaysia as there was only first subsidiary management corporation which proposed to be formed. The low establishment of subsidiary management corporation might be the Management Corporation or proprietor do not fully understand the important and benefits to establish limited common property. Other than that, it might be the difficulty face by Management Corporation in the procedure to establish the limited common property such as the preparation to get approval for the special plan or this problem in relation to the quit rent of the strata scheme.

The involvement of Common Pool Resource Theory could define the important of establish the limited common property. If the proprietors more understanding about the establishment of limited common property, it could help in the increment of establishment and in the same time helps the fairness of distribution toward the strata scheme.

\section{REFERENCES}

1. REHDA, I. (2018). Strata Management Handbook. Selangor, Malaysia: REHDA Institute. 5 April 2018. Selangor, Malaysia: International Law Book Services.
2. Strata Titles Act 1985 (Act 318), Rules \& Orders. (2018). As at

3. Tan, Liat Choon, Ujang, M. U. B., Thoo, Ai Chin, Ng, See Eng, Goh, Leong Sen, Hasan, M. H. B. A., \& Shah, S. N. W. B. M. (2016). Condominium Rights in Malaysia. Advanced Science Letters, 22(22), 4194-4196.

4. Shukri, I. M., \& Maidin, A. J. (2010). Malaysia Strata Titles Law and Procedure. Selangor, Malaysia: Sweet \& Maxwell Asia.

5. Strata Management Act 2013 (Act 757) \& Regulations. (2015). As at 15 July 2015. Selangor, Malaysia: International Law Book Services.

6. Survey and Mapping Director General Circular (PKPUP), Ref.1 (2017). Garis Panduan Mengenai Penyediaan Pelan Khas Untuk Harta Bersama Terhad Bagi Tujuan Pemohonan Penubuhan Perbadanan Pengurusan Subsidiari. As at 31 May 2017. Kuala Lumpur, Malaysia: Department of Survey and Mapping Malaysia.

7. EdgeProp. (2018, February 17). First Sub-MC in Malaysia to be formed. Retrieved from https://www.edgeprop.my/content/1285237/first-sub-mcmalaysia-be-formed.

8. Federal Lands and Mines Director General Circular (PKPTG), Ref 6/2014. (2014). Penubuhan Perbadanan Pengurusan Subsidiari. As at 29 October 2014. Putrajaya, Malaysia: Department of Director General of Lands and Mines Malaysia, Ministry of Water, Land and Natural Resources.

9. Tan, Liat Choon (2013). Towards Developing A Threedimensional Cadastre For Three-dimensional Property Rights In Malaysia. (Ph.D. thesis), Universiti Teknologi Malaysia.

10. 10. Paulsson, J. (2007). 3D Property Rights-An Analysis of Key Factor Based on International Experience. (Ph.D Thesis), Royal Institute of Technology, Stockholm, Sweden.

11. Chris, T. (2015). Owner's Manual \& Guidebook. Kuala Lumpur, Malaysia: Catizens Sdn Bhd.

12. Stevenson, G. G. (1991). Common Property Economics - A General Theory and Land Use Applications (1st ed.). United States of America: Cambridge University Press, New York. 
13. Hussain, J. (1999). Strata Title in Malaysia (1st ed.). Selangor, Malaysia: Pelanduk Publication (M) Sdn Bhd.

14. Christudason, A. (2008). Legislation affecting common property management in Singapore. Property Management, 26(3), 207219.

15. Ostrom, E. (1990). Governing the Commons: The Evolution of Institutions for Collective Action. New York: Cambridge University Press.

\section{AUTHORS PROFILE}

Tan Wee Vern, a PHD candidate from Department of Real Estate, Faculty of Built Environment and Surveying, Universiti Teknologi Malaysia (UTM), Malaysia. His PhD research is focusing on the stratified properties and regulation.

Sr. Dr. Tan Liat Choon is currently a senior lecturer at the Department of Geoinformation, Faculty of Built Environment and Surveying, Universiti Teknologi Malaysia (UTM), Malaysia. He was awarded PhD from UTM with his thesis title "Towards Developing a ThreeDimensional Cadastre for Three-dimensional Property Rights in Malaysia". His research interest focuses on 3D cadastre, stratified properties and property rights and currently he had more than 70 publications.

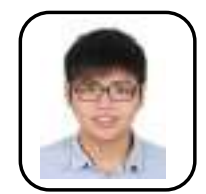

Toh Ming Liang is a PHD candidate Department of Real Estate, Faculty of Built Environment and Surveying, Universiti Teknologi Malaysia (UTM), Malaysia. His $\mathrm{PhD}$ research is focusing on the land regislation, land administration and property rights.

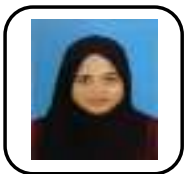

Nabilah Huda Binti Yaccub received her Degree in Bachelor of Engineering (Geomatic) in UTM. She did research about stratified properties in her Undergraduate Project.

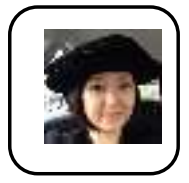

Dr. Thoo Ai Chin is a senior lecturer, internship coordinator, internal auditor and alumni committee of Azman Hashim International Business School (AHIBS). As an internship coordinator for Bachelor of Management (Marketing), she serves as a liaison between AHIBS and business/organizations in the area of marketing. Besides, as an internal auditor, she assists the university in meeting its objectives and improving the effectiveness of risk management, control and governance processes.

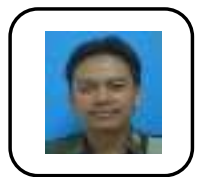

Dr. Muhamad Uznir Bin Ujang is a senior lecture at the Department of Geoinformation, Faculty of Built Environment and Surveying, University Technology Malaysia (UTM). $\mathrm{He}$ is a scientific reviewer who performed reviews for journals including ISPRS International Journal of Geo Information and Proceedings of the International Conference on Geomatics \& Geospatial Technology; placing in the 95th percentile for verified review contributions on Publons up until July 2018. With his expertise on 3D geospatial data, he has published more than 50 research items in the related field. 